\title{
Article
}

\section{Tourism, sustainable development and the theoretical divide: 20 years on}

\author{
Sharpley, Richard Anthony john \\ Available at http://clok.uclan.ac.uk/33605/ \\ Sharpley, Richard Anthony john ORCID: 0000-0002-2135-3206 (2020) Tourism, \\ sustainable development and the theoretical divide: 20 years on. Journal of \\ Sustainable Tourism, 28 (11). pp. 1932-1946. ISSN 0966-9582
}

It is advisable to refer to the publisher's version if you intend to cite from the work. http://dx.doi.org/10.1080/09669582.2020.1779732

For more information about UCLan's research in this area go to http://www.uclan.ac.uk/researchgroups/ and search for < name of research Group>.

For information about Research generally at UCLan please go to http://www.uclan.ac.uk/research/

All outputs in CLoK are protected by Intellectual Property Rights law, including Copyright law. Copyright, IPR and Moral Rights for the works on this site are retained by the individual authors and/or other copyright owners. Terms and conditions for use of this material are defined in the policies page.

\section{CLoK}

Central Lancashire online Knowledge www.clok.uclan.ac.uk

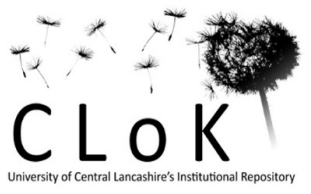


Tourism, sustainable development and the theoretical divide: 20 years on

\author{
Richard Sharpley \\ Lancashire School of Business \& Enterprise \\ University of Central Lancashire
}

\begin{abstract}
A conceptual paper published twenty years ago (Sharpley, 2000) concluded that sustainable tourism development is an unviable objective. Specifically, it argued that environmentally sound tourism development (sustainable tourism) is essential; sustainable development through tourism, however, is unachievable. Despite continuing alignment between tourism and sustainable development in both academic and policy circles, not only have the intervening two decades proved this argument in practice to be correct, but also there is little evidence of a more sustainable tourism sector. This paper, therefore, returns to the theoretical relationship between tourism and sustainable development, considering more recent transformations in understandings of the concept of development as well as contemporary approaches to sustainable development. Highlighting the controversy surrounding the continuing adherence to economic growth in development policy in general and tourism development in particular, it discusses sustainable de-growth as an alternative approach to development and, in the context of increasing concerns over climate change, the specific implications for tourism.
\end{abstract}

Key words: Sustainable tourism; sustainable development; economic growth model; sustainable de-growth

\title{
Introduction
}

Twenty years ago, I published a paper in the Journal of Sustainable Tourism that sought to establish 'a theoretical bridge between sustainable tourism and the broader framework of sustainable development' (Sharpley, 2000: 2). The purpose of doing so was twofold. First, despite a decade of academic debate - one of the earlier contributions was a dedicated conference in 1990 (Howie, 1990) - the concept of sustainable tourism development remained based on fragile theoretical foundations. More specifically, despite already existing concerns with regards to its inherent contradictions (Redclift, 1987), sustainable development in general had been, with some notable exceptions (for example, Butler, 1998; Mowforth \& Munt, 1997), adopted uncritically, at least in academic circles, as both a framework for and objective of tourism development in particular. This was, perhaps, unsurprising given that not only had tourism long been sanctioned and adopted as a vehicle of 'development' (Jenkins, 1991; WTO, 1980) but also that, by 2000, sustainable development had become the dominant 
global development paradigm (Lafferty \& Eckerberg, 2013). Nevertheless, the need existed for a more thorough and theoretically-informed understanding of the relationship between tourism and sustainable development, not least to inform the debate that had become polarised around, on the one hand, sustainable tourism (or sustaining tourism as a specific activity, thereby effectively divorcing it from broader developmental objectives) and, on the other hand, sustainable tourism development - that is, tourism as a vehicle of sustainable development (Hunter, 1995).

The second and consequential purpose of the paper was to map tourism onto a conceptual model of the principles and objectives of sustainable development in order to identify areas of convergence and / or divergence. In other words, it sought to consider the extent to which the concept of sustainable tourism development could be translated into practice or, more simply stated, whether it represented a viable outcome of tourism development. This mapping exercise indicated that sustainable tourism development is unachievable. That is, the paper concluded that although it is incumbent on all stakeholders to seek or encourage more sustainable forms of tourism - in contemporary parlance, to act 'responsibly' (Fennell, 2008; Goodwin, 2011) - this should be done 'without hiding behind the politically acceptable yet... inappropriate banner of sustainable development' (Sharpley, 2000: 15).

Since the paper was published, the literature on sustainable tourism has burgeoned in both scale and scope. Some years ago, for example, Buckley (2012) suggested that, overall, the number of related research publications was in excess of 5000; similarly, Niñerola, Sánchez-Rebull \& Hernández-Lara (2019) identified 4647 papers published between 1987 and 2018 that focus on sustainability issues in tourism. In addition, both these and other reviews (Bramwell, Higham, Lane \& Miller, 2017; Lu \& Nepal, 2009; Ruhanen, Weiler, Moyle \& McLennan, 2015) reveal the extent of evolving research themes and trends in sustainable tourism, one of the more recent of which has inevitably been a focus on the relationship between tourism and climate change. However, whilst these reviews point to the maturation of sustainable tourism as a field of research as well as its increasing centrality to tourism research more generally, two points deserve emphasis.

First, as Ruhanen et al (2015: 518) observe, the concept of 'sustainable tourism developed alongside, but separate to, its parent paradigm of sustainable development' and, for the most part, the research continues to be defined by this distinction. Alternatively stated, early conceptualisations of sustainable tourism development firmly located it within the context of sustainable development - tourism, which (as with any form of production / 
consumption) should itself be environmentally sustainable, should also be an element of a broader sustainable development strategy (Cronin, 1990; Hunter, 1995). Almost immediately, however, the former (sustaining tourism) took precedence over the latter (sustainable tourism development), it perhaps being assumed that achieving sustainable tourism will inevitably contribute to sustainable development. Certainly, Bramwell et al (2017: 1) argue that 'sustainable tourism is often now seen as a normative orientation... toward sustainable development' whilst it is notable that, following the announcement of the Sustainable Development Goals (SDGs) in 2015 (UN, n.d.), the United Nations declared 2017 as the International Year of Sustainable Tourism for Development, not of 'tourism for sustainable development'. As a consequence, although certain themes, such as pro-poor tourism, community-based tourism or volunteer tourism, are implicitly linked to the alternative development agenda (Friedmann, 1992), and although there can be no doubting its contribution and significance, the research into sustainable tourism has evolved largely in isolation from transformations in development thought and practice, from critiques of sustainable development and, indeed, from questions surrounding development (sustainable or otherwise) as the objective of tourism more generally

Second, and putting it bluntly, sustainable tourism research and policy appear to occupy a parallel universe to the practice of tourism. In other words, despite the extensive academic attention paid to sustainable tourism in the literature and, from the industry perspective, numerous accreditation schemes (Font, 2002), a variety of sectoral initiatives, the development of sustainability indicators (Tanguay, Rajaonson \&Therrien, 2013; UNWTO, 2004), the establishment of bodies such as the Global Sustainable Tourism Council (GSTC) and other initiatives, the last twenty years have witnessed little if any evidence of progress towards the achievement of sustainable tourism development or, indeed, of a more sustainable tourism sector (Buckley, 2012).

This may be explained, in part, by the origins of the concept of sustainable tourism development. The 1980s and early 1990s were notable for increasing concern, primarily amongst academics but also in the popular media, with regards to the impacts of, specifically, mass tourism (Poon, 1993), described by one commentator in apocalyptic terms as a 'spectre haunting our planet' (Croall, 1995: 1). Hence, building on the work of the early proponents of so-called 'alternative tourism' (Smith \& Eadington, 1992), sustainable tourism development rapidly garnered support as an alterative to mass tourism (Pigram, 1990), not only as a means of addressing its negative consequences but also of challenging what many considered (and still consider) to be a manifestation of neoliberal capitalism (Mosedale, 2016). Inevitably, 
such an argument was not attractive to the travel and tourism industry and, consequently, not only have debates surrounding sustainable tourism development largely remained within academic circles - or as Murphy (1998: 187) observed some time ago, 'the message about sustainable tourism seems to have become trapped in an academic-government loop' - but also there is limited documented evidence of effective collaboration between the tourism academy and industry (but, see Higuchi \& Yamanaka, 2017). Moreover, although global bodies such as the World Tourism Organisation and World Travel and Tourism Council were quick to embrace the concept of sustainable tourism development, they have arguably done so in order to 'greenwash' their explicit growth agendas.

Nevertheless, it must be acknowledged that not only is there much evidence of increasing supply and consumption of more sustainable forms of tourism, from innumerable destination-specific initiatives to regional policy developments, such as the EuroVelo, a trans-European cycle route network project (Weston et al., 2012). This issue is returned to later but the important point here, however, is that progress towards the achievement of sustainable tourism development can only be considered at the global level. It is this context that a number of fundamental trends in international tourism since 2000 contradict the pervasive reference to sustainability in many tourism development policy documents (Hall, 2013; Torkington, Stanford \& Guiver, 2020). For instance:

- Annual international tourist arrival figures have increased exponentially, from 687 million in 2000 to 1.401 billion in 2018 (UNWTO, 2019). In other words, in less than two decades, annual tourist arrivals more than doubled whilst, more specifically, global air passenger numbers (including domestic flights) almost tripled over the same period, from 1.674 billion to 4.233 billion (World Bank, 2019). At the same time, annual international tourist receipts grew from US $\$ 481$ billion to US\$1451 billion. From an economic perspective and that of the UN World Tourism Organization (UNWTO), such growth in tourism may be considered a success story; however, it is environmentally and as evidenced, for example, by the emergence of anti-tourism movements (Hughes, 2018), socially unsustainable.

- Much of this growth has been accounted for by the emergence of new markets, notably China, as well as a greater propensity to travel amongst existing markets. Yet, less than one sixth of the global population currently engages in international travel, pointing on the one hand to significant global inequity in the opportunity to travel but, 
on the other hand, the potential for continuing future growth driven by emerging tourism markets.

- The growth of international tourism has been largely underpinned by, on the one hand, increasing wealth, particularly in emerging economies, and, on the other hand, a neo-liberal agenda that has facilitated the expansion of the travel and tourism sector (Fletcher, 2011). Much attention has been paid recently to the relationship between the growth of the so-called sharing economy or peer-to-peer (P2P) accommodation sector and what is euphemistically referred to as 'overtourism' (Milano, Cheer \& Novelli 2019; Peeters et al., 2018). However, of arguably greater significance over the last two decades has been the expansion of the low-cost carriers (LCCs) sector. In 2006, LLCs accounted for 15.7 percent of the global airline market; by 2018, this had risen to 31 percent of the market which, as noted above, had grown significantly (Statistica, 2019). Moreover, there are currently more than 130 LLCs in operation globally (ICAO, 2017), primarily operating on short-haul routes which have relativel high per passenger carbon emissions (Miyoshim \& Mason, 2009).

- Newer destinations have been developed whilst established destinations are, for the most part, attracting ever-increasing numbers of tourists. Of the 217 nation states listed in the UNWTO's international tourism statistics for 2017, 108 (that is, half of all national destinations) received more than one million tourists that year; of these, 73 attracted more than three million tourists and 35 more than ten million tourists (extrapolated from UNWTO, 2018). In some cases, this is resulting in significant dependency on tourism. In 11 national economies, the total (direct and indirect) contribution of tourism to GDP exceeds 40 percent and, in 44 national economies, accounts for 15 percent or more of GDP. Such a degree of dependency (indeed, any level of dependency) contradicts the inherent focus on self-reliance which has long been an objective of development (Goulet, 1978) (see Table 1).

In short, the trajectory of tourism on a global scale contrasts starkly with the policies and principles of sustainable tourism development that have been advocated over the last two decades. However, such policies remain in evidence, not least through the alignment of tourism with the SDGs. For example, the UNWTO, through its 'T4SDG' platform, claims that 'Tourism, as an economic powerhouse, has the potential to contribute, directly or indirectly to all of the [sustainable development] goals' (see http://tourism4sdgs.org/tourism- 
for-sdgs/tourism-and-sdgs/) whilst the Tourism and the Sustainable Development Goals Journey to 2023 report similarly suggests that 'Tourism's role in achieving the 17 SDGs can be significantly strengthened when sustainable development becomes a shared responsibility and moves to the core of decision-making within the tourism sector' (UNWTO/UNDP, 2017: 10). At the same time, however, there is clear evidence of increasing concerns with regards to the unsustainability of the unbridled growth of tourism, concerns which were first expressed more than half a century ago (Mishan, 1969) but which have become focused on the contribution of tourism in general and of aviation in particular to climate change (Stovall, Higham \& Stephenson, 2019).

Table 1: Contribution of travel and tourism to GDP 2017: Top 50 countries

\begin{tabular}{|lc|lc|lr|}
\hline Country & $\begin{array}{c}\text { \% of } \\
\text { GDP }\end{array}$ & Country & $\begin{array}{c}\text { \% of } \\
\text { GDP }\end{array}$ & Country & $\begin{array}{c}\text { \% of } \\
\text { GDP }\end{array}$ \\
\hline Maldives & 76.6 & St Kitts \& Nevis & 26.8 & Tonga & 18.2 \\
Seychelles & 65.3 & Albania & 26.2 & New Zealand & 17.9 \\
Macao & 61.3 & Croatia & 25.0 & Portugal & 17.3 \\
Antigua \& Barbuda & 51.8 & Sao Tome \& Principe & 24.3 & Dominican Republic & 17.2 \\
Bahamas & 47.8 & Mauritius & 23.8 & Hong Kong (China) & 16.7 \\
Vanuatu & 46.1 & Montenegro & 23.7 & Madagascar & 16.6 \\
Cape Verde & 44.9 & St Vincent \& Grenadines & 23.4 & Mexico & 16.0 \\
St Lucia & 41.8 & Grenada & 23.3 & Armenia & 15.7 \\
Belize & 41.3 & Cyprus & 22.3 & Estonia & 15.4 \\
Barbados & 40.6 & Thailand & 21.2 & Honduras & 15.0 \\
Fiji & 40.3 & Philippines & 21.1 & Spain & 14.9 \\
Dominica & 36.6 & Kiribati & 20.9 & Austria & 14.6 \\
Iceland & 34.6 & Gambia & 20.1 & Azerbaijan & 14.6 \\
Jamaica & 32.9 & Greece & 19.7 & Panama \\
Cambodia & 32.4 & Jordan & 18.7 & Tunisia & 14.5 \\
Georgia & 31.0 & Morocco & 18.6 & Namibia & 14.2 \\
Malta & 27.1 & Lebanon & 18.4 & & 13.8 \\
\hline Source: Adapta & & & \\
\hline
\end{tabular}

Source: Adapted from World Atlas Data (2018)

To summarise, then, the theoretical divide identified twenty years ago between tourism and sustainable development (Sharpley, 2000) has become manifested in a divide between tourism theory / policy and practice. It is, therefore, both timely and appropriate, not least given the increasing attention paid to global warming and climate change, to revisit the concept of sustainable development and its relevance to tourism, in particular exploring the 
underlying advocacy (and inherent contradictions) of economic growth within contemporary sustainable development policy as established by the SDGs. More specifically, this paper seeks first to relate transformations in conceptualisations of 'development' to the relationship between tourism and (sustainable) development, arguing that a causal link between tourism and development can no longer be justified. It then goes on to challenge the primacy of the economic growth model in sustainable development policies in general, and tourism policies in particular, pointing to the need for a fundamental re-think about how tourism is produced, managed and consumed.

\section{The end of tourism as 'development'?}

Development is an ambiguous term that, although widely applied in many and diverse contexts, defies precise definition (Cowen \& Shenton, 1996). Broadly, however, it is considered to be both the process through which a nation or society moves from one condition towards another (presumably better) condition and also the goal of that process. In other words, it 'refers both to the destination of a journey and to the journey itself' (Goulet, 1968: 388). Immediately, then, the concept of development is problematic; 'any improvement of complex systems, as indeed actual socio-economic systems are, can occur in different parts or ways, at different speeds and driven by different forces. Additionally, the development of one part of the system may be detrimental to the development of other parts, giving rise to conflicting objectives (trade-offs) and conflicts' (Bellù, 2011). Moreover, the goals of development should be established only by the individuals and societies undertaking the journey towards it (Hettne, 2009) - there can be no universally accepted measure of being 'developed' - and, moreover, by definition it can never be reached.

Despite this ambiguity, not only has 'development' long been considered both a desirable outcome and specific objective of tourism development but also, for many destinations as well as organisations such as the UNWTO, it continues to be seen in this light. However, whilst such an association between tourism and development might once have been appropriate, transformations in understandings of what development is and how it may be achieved suggest that this is no longer the case. In other words, it was once logical to align tourism with development, not least because the perceived (primarily economic) contributions of the former, such as the generation of income, employment and government revenues and the stimulation of linkages throughout the economy, closely reflected early conceptualisation of the latter. Not only was development - which was first established as a global process and objective in the dynamic political-economic environment in the decade 
following the Second World War (Rist, 2019) - initially considered to be synonymous with economic growth (Mabogunje, 1980) but also international development policy was based upon classical economic theory of stimulating the economy focused around economic growth poles (Potter, 2014) or the so-called modernisation development paradigm (Peet \& Hartwick, 2015). Moreover, the academic study of development first evolved as a branch of development economics, further entrenching the 'positivist orthodoxy' (Leys, 1995: 7) of economic planning as a means of achieving development.

The perceived developmental benefits of tourism continue to be defined primarily in economic terms in destination policies and by bodies such as the UNWTO and World Travel and Tourism Council (WTTC), despite their apparent 'buy in' to the notion of sustainable development (WTTC, n.d.). However, the 'meaning' of development (Seers, 1969, 1977) and, indeed, global development policy has undergone significant transformation over the last half century. As is well documented (see Knutsson, 2009, for a summary), it soon came to be recognised that economic growth alone, as well as the policies designed to achieve it, typically failed to resolve social and political challenges and, in some cases, served only to exacerbate them. Hence, although economic growth remained a cornerstone, development came to address social challenges such as unemployment and inequality (the latter continuing to represent a significant barrier to the achievement of development on a global scale; see UNDP, 2019) and, by the start of the new millennium, its focus was firmly on human (as opposed to economic) development, embracing 'social, cultural and political components' as well as the economic dimension (Sharpley, 2000: 4).

This is not to say that economic growth and broader development are mutually exclusive. As discussed shortly, economic growth (or more precisely, an appropriate level of national and per capita income) remains a prerequisite to development. As research by Sachs, Stevenson and Wolfers (2010) reveals, enhanced subjective well-being correlates with increases in material living standards (see also Veenhoven \& Vergunst, 2014 and, for an opposing perspective, Schimmel, 2007). Nevertheless, over the last three decades or so, development has become associated with the notion of well-being at both the societal and, importantly, individual level. For Sen (1999), such well-being is dependent on the possession of capabilities to fulfil what he refers to as functionings, giving individuals the freedom - that is, freedom of choice and freedom from servitude to ignorance, nature, other societies, beliefs and institutions (Sharpley, 2015) - to live the life they wish, to fulfil their potential as individuals and members of societies. Similarly, the UNDP (2010: 22) defines human development as 'the expansion of people's freedoms to live long, healthy and creative lives; 
to advance other goals they have reason to value; and to engage actively in shaping development equitably and sustainably on a shared planet'.

A sense of well-being is inevitably dependent, in part, upon the achievement of traditional, tangible indicators of development, such as income, education, longevity, access to health care and other services and resources, and so on. It is also dependent, as acknowledged by the UNDP (2019), on greater equality both within and between nations. Yet, as discussed in more detail later in this paper, an inherent irony of economic development and growth is that, typically, it enhances inequality (Wilkinson \& Pickett, 2010); many developed nations, though enjoying increases in per capita wealth, are suffering a 'social recession' (Rutherford, 2008). At the same time, however, well-being is also dependent on intangible factors which, according to Jackson (2017), contribute to living a good or, in the traditional sense of the word, prosperous life - the etymological roots of prosperity are pro spere, or according to hope and expectation. Hence, for Jackson (2017), to be prosperous is to be fulfilled, to be satisfying a variety of social, psychological and perhaps spiritual needs. Consequently, prosperity or well-being, in addition to the satisfaction of basic needs, might emanate from feeling part of and contributing to society, respecting and being respected by others, having a sense of purpose and identity, and even fulfilling a moral responsibility for the well-being of others both in the present and future.

Qizilbash (1996: 157) refers to development simply as the process of 'people's lives going better'; this is arguably the most straightforward definition of development. He goes on, however, to suggest that it should be understood in terms of what he calls 'prudential values', or those things that people consider make their life, and the lives of others, better. Not all such values will be relevant for all people but broadly they embrace all of the elements of development discussed above: basic needs; human capacity (including physical and intellectual skills); freedom (in Sen's (1999) interpretation); and prosperity as defined by Jackson (2017).

From this perspective, it is evident that development is multi-dimensional and highly variable in how it is understood by individuals and societies. Some of its elements are core, such as the satisfaction of basic needs, an appropriate level of income and access to social goods, all of which are dependent on economic growth; others will vary. This implies that there can be no universally defined goal of development and, by extension, no universal policy or process through which it might be achieved. Indeed, it is for this reason, as well as evidence of entrenched developmental challenges on the global scale, that some argue that development as a global project has failed and should be abandoned (Rahnema, 1997; 
Sidaway, 2007). In turn, this suggests that generalised claims of tourism's contribution to development are untenable; it has become inappropriate to promote tourism as a vehicle of development as defined here. In other words, there is no doubt that tourism, as a major economic sector, may (but not inevitably) stimulate economic activity and contribute to economic growth in destination areas. However, the extent to which individuals and societies may achieve well-being or become prosperous is dependent on numerous endogenous factors independent of the economic benefits accruing (or not) from tourism.

This is not, of course, a new argument. It has long been acknowledged not only that tourism is, in essence, an industrial activity with consequences 'similar to most other industrial activities' (McKercher, 1993: 14) that challenge notions of sustainability, but also that it is no more likely to contribute directly to development than any other economic activity (Young, 1973). However, although more recent conceptualisations of development as discussed above serve to reinforce the need to disentangle the association between tourism and development, not only is that association maintained within policy (and, to an extent, academic) circles but also it is manifested primarily in reference to sustainable development, a concept that over the last two decades has arguably become increasingly discredited.

\section{From sustainable development to sustainable de-growth}

As is well known, the concept of sustainable development initially evolved during the 1970s (Du Pisani, 2006) but gained international recognition and endorsement with the publication in 1987 of the Brundtland Commission's report, Our Common Future (WCED, 1987). Since then, it has become and remains, on the one hand, the dominant global development paradigm but, on the other hand, the focus of significant controversy. Generally, that controversy reflects the ambiguity of the concept (Robinson, 2004) or what Kates, Parris and Leiserowitz (2005: 13) refer to as its 'inherent malleability'. That is, sustainable development possesses 'a chameleon-like capacity... to mean all things all people' (Adelman, 2017: 7) that for some, limits its viability as a process and objective of development but, for others, is its strength in as much as it offers a compromise between the competing positions of environmental protection and economic growth and development (Skolimowski, 1995).

A full consideration of the relevant debates is well beyond the scope of this paper but it is important to note that, irrespective of definitional and other controversies, sustainable development represents a response to the acknowledged inseparability of the environment and human existence and development; that is, it seeks to 'enact a positive vision of a world in which basic human needs are met without destroying or irrevocably degrading the natural 
systems on which we all depend' (Kates et al., 2005: 20). Inevitably, this vision is subject to competing philosophical positions, from ecocentrism that promotes the intrinsic and moral value in nature to anthropocentrism which, in essence, gives primacy to human interests in how nature is perceived and exploited. Cutting across this divide, however, is the inescapable need to achieve environmental sustainability, to maintain the so-called source and sink functions of the global ecosystem. In other words, the ability of humanity to enjoy what Porritt (2007: 33) describes as the 'capacity for continuance into the long term future' is dependent on achieving an appropriate balance between the variables in the global ecosystem, as summarised in Sharpley (2000: 6-7): (a) the rate at which the stock of natural (non-renewable) resources is depleted relative to the development of substitute, renewable resources, (b) the rate at which waste is deposited back into the ecosystem relative to the assimilative capacity of the environment, and (c) global population levels and per capita levels of consumption (Goodland, 1992).

Drawing on Lélé's (1991) still relevant observation that sustainable development is, in simple terms, a function of sustainability plus development, the sustainability side of this equation is fixed and unarguable; given the finite and fragile natural resource base upon which humanity depends, the balance described above must be achieved. This, in turn, not only only challenges the widely-advocated, anthropocentric notion of the 'triple bottom line' or, as Marco (2005: 5) puts it, human well-being on a global scale is dependent on the wellbeing of the ecosystem and, hence the ecosystem 'is to be regarded as a superordinated system to the other dimensions' of sustainable development. It also points to the key issue within sustainable development debates - how society organises itself, including through its economic structures and processes, to achieve environmental sustainability whilst seeking social 'development' (or well-being) on a global scale. And it is in this context that the concept of sustainable development has become increasingly criticised and, by some, discredited, primarily as a result of the priority that continues to be given to economic growth in sustainable development policies, including the SDGs (Adelman, 2017).

\section{Challenging the economic growth model}

Undoubtedly, some degree of economic growth is both desirable and necessary in order for societies as a whole to not only have their basic needs satisfied but also to benefit from goods and services that contribute to their well-being. More specifically, it is also considered a vital ingredient of strategies to reduce levels of poverty - strategies which often, of course, include tourism (Mitchell \& Ashley, 2010) - although given the multidimensional nature of poverty 
(Misturelli \& Heffernan, 2008), economic growth alone is insufficient. Indeed, given the fact that poverty is not absolute but relative (Foster, 1998) and that, as noted above, many wealthier countries are experiencing increasing wealth inequality (Wilkinson \& Pickett, 2010), economic growth may ironically maintain or even enhance levels of poverty. It is for this reason, amongst others, that many now draw attention to what is referred to by Pilling (2018) as the 'growth delusion' (see also Lloyd, 2009) and the limitations of GDP as a measure of development (or progress) in general, and to the increasingly tenuous relationship between economic growth and environmental sustainability in particular. Specifically, continuing economic growth is dependent upon the continuing exploitation of natural, nonrenewable resources (Heinberg, 2010) which is, by definition, unsustainable; at the same time, it is argued that there are 'unrealistic expectations of efficiency improvements or technological breakthroughs' (Kallis, 2011: 874) - that is, absolute or even relative (to increasing output) de-coupling of production-based economic growth from natural resource use is, in all likelihood, impossible (Ward, et al., 2016). Hence, the recent claims by the UK's Sustainable Aviation group that UK aviation will be carbon neutral by 2050 , despite a projected 70 percent increase in passenger numbers (Adams, 2020), should be treated with a significant degree of caution. As Daly (1990: 1) argued three decades ago, 'it is clear that growth of the economy cannot be [environmentally] sustainable over long periods of time. The term sustainable growth should be rejected as a bad oxymoron'.

Nevertheless, the concept of sustainable development has, from the outset, been based upon the premise of economic growth; most definitions of it 'perpetuate instrumental rationality, progress, economic growth and conceive nature as capital' (Adelman, 2017: 23). That is, a particularly anthropogenic perspective is evident in the underpinning thesis of most sustainable development policies, that resource conservation is necessary primarily to support future human development based on economic growth. The Brundtland report is, for example, replete with explicit references for economic growth, suggesting with no irony that global economic growth by a factor of 5 to 10 is necessary to achieve sustainable development (WCED, 1987: 50), though relying on undefined, unexplained and arguably unrealistic expectations of future technological innovation. The more recent SDGs similarly promote economic growth as the principal mechanism for reducing poverty and supporting development more generally, reflecting Pilling's (2018) argument that 'the size of national income is valued more than the quality of economic activity and its relationship to human and ecological wellbeing' (Adelman, 2017: 33). Certainly, many of the 17 goals are both justifiable and necessary for a more equitable and, indeed, sustainable world in which well- 
being is enjoyed by the majority, if not all, of the global population. However, as Adelman (2017) critiques in more detail, there exist many inherent contradictions within the SDGs that emanate from its inherent economic growth message. For example, Goal 8 ('decent work and economic growth') proposes annual economic growth of at least seven percent per annum in the least developed countries and sustained economic growth elsewhere, contradicting ambitious environmental objectives established elsewhere in the SDGs, whilst Goal 10 ('reduce inequality within and among countries') competes with incontrovertible evidence that not only does economic growth increase, rather than reduce, inequality but also that such inequality tends to diminish social well-being. This is convincingly demonstrated by Wilkinson and Pickett (2010: 5-6) who, in the introductory chapter to their book The Spirit Level: Why Equality is Better for Everyone, argue that increases in wealth and, commensurately, in inequality in affluent societies has resulted in 'long-term rises in rates of anxiety, depression and numerous other social problems' that are less pervasive in more equal (in terms of individual wealth) societies.

As a consequence, the last decade has witnessed more widespread advocacy for the notion of de-growth in the context of both sustainable development generally (MartínezAlier, Pascual, Vivien \& Zaccai, 2010) and, to a lesser extent, tourism development in particular (Andriotis, 2018; Higgins-Desbiolles et al., 2019; Hall, 2009). In other words, it is argued that following the path of economic growth, typically measured by an increase in GDP, is neither conducive to enhancing individual or societal well-being nor compatible with environmental sustainability (Martinez-Alier, 2009) and, hence, that continuing adherence to the goals and objectives of sustainable development is no longer appropriate. Rather, there is a need for 'systemic political, institutional and cultural change...in order to create a different system where expansion will no longer be a necessity' (Kallis, 2011: 875) and, in particular, where society's throughput - global demands on the ecosystem's sink and source functions are reduced. This, in turn, will 'inevitably entail a smaller - and quantitatively different economy' (Kallis, 2011: 874) or, more precisely, de-growth.

The concept of de-growth is often traced back to the work of Georgescu-Roegen (1979) and what he termed 'décroissance' but became more established as an intellectual movement through the work of Serge Latouche (2004). A variously interpreted and complex ambition (Andriotis, 2018), it is an approach to social and economic development that attracts significant criticism, not least because of what some see as the impossibility of achieving degrowth within a capitalist system (Foster, 2011) and others as the unlikelihood of its acceptance by the mainstream given its radical position. In simple terms, it requires a 
reduction in both production and consumption on the global scale along with a fundamental shift in society's understanding of the relationship between consumption, wealth and wellbeing. This, in turn, requires a rebalancing between wealthier and less prosperous societies; pragmatically, the throughput of developed nations must be reduced significantly in order to achieve an equitable worldwide 'compromise' level of well-being. And it is this latter requirement that perhaps represents the greatest challenge to sustainable de-growth. Nevertheless, as is now argued, the environmental consequences of tourism, in particular its aviation-related contribution to global warming, are now such that de-growth is necessary.

\section{Tourism, sustainability and de-growth}

The inexorable growth of tourism, both international and domestic, has resulted in what has recently come to be referred to as 'overtourism' (Alexis, 2017; Dodds \& Butler, 2019; Milano et al., 2019). Though open to interpretation and definition (Koens, Postma \& Papp, 2018), it is typically used to describe a situation in which the physical, psychological, economic and social capacity of a destination has been exceeded at a particular time. As such, it can be considered to be, in some respects, simply a new term for an old phenomenon numerous destinations around the world have long suffered overtourism - although in its contemporary manifestation it is most commonly associated with city tourism and the emergence of local anti-tourism sentiment.

Undoubtedly, overtourism (as commonly understood) represents a significant challenge for many destinations, in particular those cities that find themselves facing everincreasing tourist arrivals driven in no small measure by the popularity of the $\mathrm{P} 2 \mathrm{P}$ accommodation sector. The important point, however, is that overtourism is not the problem; rather, it is the symptom of a broader issue. Simply stated, the excessive touristic demands placed on destinations are fuelled by, on the one hand, the continuing expansion of the tourism industry seeking to profit from tourism and, on the other hand, the increasing consumption of tourism experiences manifested in the growth in both the overall number of tourists and, significantly, the consumption of tourism by individual tourists. Putting it another way, overtourism is a symptom of the economic growth model, discussed in the preceding section, that permeates contemporary (sustainable) development policy in general and tourism development policy in particular. At the global level, the UNWTO celebrates annual increases in tourist arrivals whilst research has revealed the predominant focus on quantitative growth at the national level (Torkington, et al., 2020). 
It is also important to note that, as with the parochial academic focus on sustaining tourism (as opposed to sustainable tourism development) over the last two decades, the failure to recognise the symptomatic nature of overtourism is resulting proposed solutions at the destinational level that are not new; for example, typical responses such as de-marketing, visitor dispersal or capacity management have long been discussed in the visitor management literature and implemented with varying degrees of success in practice. At the same time, the notion of de-growth is often misinterpreted as simply the need to reduce the number of tourists at a particular place and time, a destinational focus that diverts attention from the more significant (in environmental impact terms) element of tourism, namely, travel to the destination. As a consequence, the tourism sector, in economic terms, continues to grow, as does the consumption of tourism to the extent that many tourists now suffer what might be described as obesity of experience.

Nevertheless, it would be erroneous to claim that all tourism is unsustainable. As observed earlier in this paper, various forms of tourism development, such as rural and agritourism, cycle or walking tourism trails and so on, reflect the principles of sustainable development whilst there are numerous examples of successful sustainable tourism projects around the world, some gaining recognition through, for example, the annual Tourism for Tomorrow awards. Equally, it has long been recognised that, with effective management, tourism can not only be balanced with conservation in national parks and other protected areas areas but may also contribute positively towards conservation measures (Eagles, 2004; FNNPE, 1997) although research has shown that this is neither as widespread or as effective as it might be (Job, Becken \& Lane, 2017; Sharpley \& Pearce, 2007). Either way, however, these are, in effect, what Wheeller (1991:93) described as a 'micro solution to a macro problem'. And that problem is, on a collective global scale, the excessive and unsustainable production and consumption of tourism.

If, as many now suggest, that the global policy of sustainable development in general should be replaced with a focus on sustainable de-growth and, more specifically, that practical measures should be adopted to address global warming through limiting carbon emissions, there is evidently a pressing need to reduce the throughput of tourism in particular. And if this is to be achieved, the only solution is to reduce, on a global scale, fossil fuel-based travel, specifically air travel; anything else would be to merely tinker with the problem. The arguments are both well-rehearsed and persuasive, and do not need to be repeated at length here - indeed, it is not the intention of this paper to do so. However, as Higham and Font (2020) have recently summarised, lifestyle (non-essential) air travel is a major contributor to 
global warming, travel contributes a major proportion of tourism's overall carbon emissions and air travel is characterised by significant inequalities. Not only does a small proportion of the global population have access to air travel but it is also accounted for by a relatively small proportion of frequent flyers. In short, at a per capita level, an absolute (privileged) minority of the global population is individually responsible for an enormous contribution to carbon emissions, the consequences of which are becoming significant for the global population as a whole. Hence, on the basis of both equity and the need to address global warming, a decrease in air travel is essential. How this might be achieved (voluntary transformations in consumer behaviour, taxation, regulation) is debatable although, at the time of writing, some consider it be the likely longer-term outcome of the impact of the Covid-19 crisis on the airline sector (Calder, 2020). Whether it must take place, however, is not.

\section{Conclusion}

The purpose of this paper was not been to prescribe a new approach to the production and consumption of tourism. Rather, it set out to revisit the theoretical relationship between tourism, as a specific and widely adopted vehicle of development, and sustainable development as the implicit objective of tourism in the context of contemporary developmental policies. In so doing, it has argued that, over the last two decades, the goal of development has evolved into the concept of well-being or 'prosperity' whereby societies and, in particular, individuals within societies, are able to enjoy meaningful, fulfilled and hopeful lives dependent upon the satisfaction of basic needs but not necessarily upon the continual pursuit of material wealth. It has also argued that although contemporary development policies offer goals that might contribute to a more equitable, just, prosperous and environmentally sustainable world, the underpinning reliance on and promotion of economic growth contradicts those goals. Hence, sustainable de-growth is considered by many as a more appropriate path to individual and societal well-being on the global scale.

Nevertheless, tourism as an essentially economic sector with significant resource impacts has, in both academic and policy circles, remained closely aligned with the concept of sustainable development. Coincidentally or otherwise, it also not only remains firmly rooted and justified within the economic growth paradigm but also, in practice, continues to be a metaphor for the negative consequences associated with economic growth more generally. Hence, the conclusions of this theoretical discussion are inevitable. That is, if tourism is to be considered within the concept of sustainable de-growth, then is there a need to not only reconsider its role in 'development' in general but to seek means of reducing it 
environmental impact in particular, not least through addressing the excessive (by some) consumption of tourism experiences and, specifically, the significant carbon emissions associated with air travel.

This is not to say that tourism cannot retain its important function as an economic sector; indeed, it must be acknowledged that many destinations are likely to remain dependent on it. Yet, the need exists to rebalance tourism on a global basis, requiring a fundamental re-think on the meaning and significance of both the production and consumption of tourism and, perhaps, research into how the necessary institutional, structural and behavioral transformations might be achieved.

\section{References}

Adams, C. (2020) UK aviation industry promises to be carbon neutral by 2050. The Independent, 4 February. Available at: https://www.independent.co.uk/travel/newsand-advice/aviation-industry-uk-carbon-emissions-neutral-heathrow-airporta9316116.html (Accessed 17 February 2020).

Adelman, S. (2017) The Sustainable Development Goals: Anthropocentrism and neoliberalism. In D. French and L. Kotzé (Eds), Sustainable Development Goals: Law, Theory and Implementation. Cheltenham: Edward Elgar, pp. 15-40.

Alexis, P. (2017) Over-tourism and anti-tourist sentiment: An exploratory analysis and discussion. Ovidius University Annals, Economic Sciences Series, 17(2),288 293.

Andriotis, K. (2018) Degrowth in Tourism: Conceptual, Theoretical and Philosophical Issues. Wallingford: CABI.

Bellù, L. (2011) Development and Development Paradigms: A (Reasoned) Review of Prevailing Visions. EasyPol. UN Food and Agriculture Organization. Available at: http://www.fao.org/3/a-ap255e.pdf (Accessed 9 May 2020)

Bramwell, B., Higham, J., Lane, B. and Miller, G. (2017) Twenty-five years of sustainable tourism and the Journal of Sustainable Tourism: Looking back and moving forward. Journal of Sustainable Tourism, 25(1), 1-9.

Buckley, R. (2012) Sustainable tourism: Research and reality. Annals of tourism Research, 39(2), 528-546. 
Butler, R. (1998) Sustainable tourism: Looking backwards in order to progress? In C.M. Hall and M. Lew (Eds), Sustainable Tourism: A Geographical Perspective. Harlow: Longman, pp. 25-34.

Calder, S. (2020) The future of flying remains unclear but at least there is one. The Independent, 17 April. Available at: https://www.independent.co.uk/travel/news-andadvice/future-of-flying-airlines-easyjet-business-travel-flights-news-a9469291.html (Accessed 18 April 2020).

Cowen, M. and Shenton, R. (1996) Doctrines of Development. London: Routledge.

Croall, J. (1995) Preserve or Destroy: Tourism and the Environment. London: Calouste Gulbenkian Foundation.

Cronin, L. (1990) A strategy for tourism and sustainable developments. World Leisure \& Recreation, 32(3), 12-18.

Daly, H. (1990) Toward some operational principles of sustainable development. Ecological Economics, 2(1), 1-6.

Dodds, R. and Butler, R. (2019) Overtourism: Issues, Realities and Solutions. De Gruyter Oldenbourg

Du Pisani, J. (2006) Sustainable development: Historical roots of the concept. Environmental Sciences, 3(2), 83-96.

Eagles, P.F. (2004) Tourism at the fifth world parks congress, Durban, South Africa, 8-17 September 2003. Journal of Sustainable Tourism, 12(2), 169-173.

Fennell, D. (2008) Responsible tourism: A Kierkegaardian interpretation. Tourism Recreation Research, 33(1), 3-12.

Fletcher, R. (2011) Sustaining tourism, sustaining capitalism? The tourism industry's role in global capitalist expansion. Tourism Geographies, 13(3), 443-461.

FNNPE (1997) European Charter for Sustainable Development in National Parks. Grafenau: Federation of Nature and National Parks of Europe.

Font, X. (2002) Environmental certification in tourism and hospitality: progress, process and prospects. Tourism Management, 23(3), 197-205.

Foster, J. (1998) Absolute versus relative poverty. American Economic Review, 88(2), 335341.

Foster, J. (2011) Capitalism and degrowth: An impossibility theorem. Monthly Review, 62(8), 26-33. 
Friedmann, J. (1992) Empowerment: The Politics of Alternative Development. Oxford: Blackwell.

Goodland, R. (1992) The case that the world has reached limits: More precisely that current throughput growth in the global economy cannot be sustained. Population and Environment, 13(3), 167-182

Goodwin, H. (2011) Taking Responsibility for Tourism. Oxford: Goodfellow Publishers.

Goulet, D. (1968) On the goals of development. Cross Currents, 18, 387-405.

Hall, C.M. (2009) Degrowing tourism: Décroissance, sustainable consumption and steadystate tourism. Anatolia, 20(1), 46-61.

Hall, C.M. (2013) Policy learning and policy failure in sustainable tourism governance: From first-and second-order to third-order change? In B. Bramwell and B. Lane (Eds) Tourism Governance: Critical Perspectives on Governance and Sustainability. Abingdon: Routledge, pp. 249-272.

Heinberg, R. (2010) Peak Everything: Waking Up to a Century of Declines. Gabriola Island, BC: New Society Publishers.

Hettne, B. (2009) Thinking About Development. London: Zed Books.

Higgins-Desbiolles, F., Carnicelli, S., Krolikowski, C., Wijesinghe, G. and Boluk, K. (2019) Degrowing tourism: Rethinking tourism. Journal of Sustainable Tourism, 27(12), 1926-1944.

Higham. J. and Font, X. (2020) Decarbonising academia: Confronting our climate hypocrisy. Journal of Sustainable Tourism, 28(1), 1-9. DOI: 10.1080/09669582.2019.1695132

Higuchi, Y. and Yamanaka, Y. (2017) Knowledge sharing between academic researchers and tourism practitioners: A Japanese study of the practical value of embeddedness, trust and co-creation. Journal of Sustainable Tourism, 25(10), 1456-1473.

Howie, F. (Ed.) (1990) Proceedings of the Sustainable Tourism Development Conference. Edinburgh: Queen Margaret College.

Hughes, N. (2018) 'Tourists go home': Anti-tourism industry protest in Barcelona. Social Movement Studies, 17(4), 471-477.

Hunter, C. (1995) On the need to re-conceptualise sustainable tourism development. Journal of Sustainable Tourism, 3(3), 155-165.

ICAO (2017) List of Low-Cost Carriers. International Civil Aviation Organisation. Available at: https://www.icao.int/sustainability/Documents/LCC-List.pdf (Accessed 31 January 2020). 
Jackson, T. (2016) Prosperity Without Growth: Foundations for the Economy of Tomorrow, $2^{\text {nd }}$ Edn. Abingdon: Routledge.

Jenkins, C. (1991) Development strategies. In L. Lickorish, A. Jefferson, J. Bodlender and C. Jenkins (Eds), Developing Tourism Destinations. London: Longman, pp. 59-118.

Job, H., Becken, S. and Lane, B. (2017) Protected Areas in a neoliberal world and the role of tourism in supporting conservation and sustainable development: An assessment of strategic planning, zoning, impact monitoring, and tourism management at natural World Heritage Sites. Journal of Sustainable Tourism, 25(12), 1697-1718.

Kallis, GT. (2011) In defence of degrowth. Ecological Economics, 70, 873-880.

Kates, R., Parris, T. and Leiserowitz, A. (2005) What is sustainable development? Goals, indicators, values, and practice. Environment: Science and Policy for Sustainable Development, 47(3), 8-21.

Knutsson, B. (2009) The intellectual history of development: Towards a potential widening repertoire. Perspectives No. 13, Göteborgs Universitet: School of Global Studies. Available at: https://www.globalstudies.gu.se/digitalAssets/1272/1272997_Perspectives_13.pdf (Accessed 12 February 2020)

Koens, K., Postma, A. and Papp, B. (2018) Is overtourism overused? Understanding the impact of tourism in a city context. Sustainability, 10(12), 4384. DOI: $10.3990 / \mathrm{su} 10124384$

Lafferty, W.M. and Eckerberg, K. (Eds) (2013) From the Earth Summit to Local Agenda 21: Working Towards Sustainable Development. Abingdon: Routledge.

Latouche, S. (2004) Degrowth economics: Why less should be so much more. Le Monde Diplomatique, 11. Available at:

https://jussemper.org/Resources/Economic\%20Data/Resources/Degrowth\%20econom ics, \%20by\%20Serge\%20Latouche.pdf (Accessed 20 February 2020).

Lélé, S. (1991) Sustainable development: A critical review. World Development 19(6), 607621.

Leys, C. (1995) The Rise and Fall of Development Theory. Oxford: James Currey.

Lloyd, B. (2009) The growth delusion. Sustainability, 1, 516-536.

Lu, J. and Nepal, S.K. (2009) Sustainable tourism research: An analysis of papers published in the Journal of Sustainable Tourism. Journal of Sustainable Tourism, 17(1), 5-16. 
Mabogunje, A. (1980) The Development Process: A Spatial Perspective. London: Hutchinson.

Marco, K. (2005) History, definition(s) and models of sustainable development. ETH-Zurich Research Collection. Available at: https://www.researchcollection.ethz.ch/bitstream/handle/20.500.11850/53025/eth-27943-01.pdf (Accessed 12 May 2020)

Martínez-Alier, J. (2009) Socially sustainable economic de-growth. Development and Change, 40(6), 1099-1119.

Martínez-Alier, J., Pascual, U., Vivien, F.D. and Zaccai, E. (2010) Sustainable de-growth: Mapping the context, criticisms and future prospects of an emergent paradigm. Ecological Economics, 69(9), 1741-1747.

McKercher, B. (1993) Some fundamental truths about tourism: Understanding tourism's social and environmental impacts. Journal of Sustainable Tourism, 1(1), 6-16.

Milano, C., Cheer, J.M. and Novelli, M. (Eds) (2019) Overtourism: Excesses, Discontents and Measures in Travel and Tourism. Wallingford: CABI.

Misturelli, F. and Heffernan, C. (2008) What is poverty? A diachronic exploration of the discourse on poverty from the 1970s to the 2000s. The European Journal of Development Research, 20(4), 666-684.

Mitchell, J. and Ashley, C. (2010) Tourism and Poverty Reduction: Pathways to Prosperity. London: Earthscan.

Miyoshi, C. and Mason, K. (2009) The carbon emissions of selected airlines and aircraft types in three geographic markets. Journal of Air Transport Management, 15(3), 138147.

Mosedale, J. (Ed.) (2016) Neoliberalism and the Political Economy of Tourism. Abingdon: Routledge.

Mowforth, M. and Munt, I. (1998) Tourism and Sustainability: New Tourism in the Third World. London: Routledge.

Murphy, P. (1998) Tourism and sustainable development. In W.F. Theobald (Ed.), Global Tourism: The Next Decade, $2^{\text {nd }}$ Edn. Oxford: Butterworth-Heinemann, pp. 173-190.

Niñerola, A., Sánchez-Rebull, M-V. Hernández-Lara, A-B. (2019) Tourism research on sustainability: A bibliometric analysis. Sustainability, 11, 1377. DOI: $10.3390 / \mathrm{su} 11051377$

Peet, R. and Hartwick, E. (2015) Theories of Development: Contentions, Arguments, Alternatives, $3^{\text {rd }}$ Edn. New York: The Guildford Press. 
Peeters, P., Gössling, S., Klijs, J., Milano, C., Novelli, M., Dijkmans, C.H.S., Eijgelaar, E., Hartman, S., Heslinga, J., Isaac, R. and Mitas, O. (2018). Research for TRAN Committee - Overtourism: Impact and Possible Policy Responses. Brussels: European Parliament, Policy Department for Structural and Cohesion Policies. Pigram, J. (1990) Sustainable tourism: Policy considerations. Journal of Tourism Studies, $1(2), 2-9$.

Pilling, D. (2018) The Growth Delusion: The Wealth and Well-Being of Nations. London: Bloomsbury Publishing.

Poon, A. (1993) Tourism, Technology and Competitive Strategies. Wallingford: CABI.

Porritt, J. (2007) Capitalism As If The World Matters. London: Earthscan

Potter, R. (2014) The nature of development studies. In V. Desai and R. Potter (Eds), The Companion to Development Studies, $3^{\text {rd }}$ Edn. Abingdon: Routledge, pp. 16-20.

Qizilbash, M. (1996) Capabilities, well-being and human development: A survey. The Journal of Development Studies, 33(2), 143-162.

Rahnema, M. (1997) Towards post-development: Searching for signposts, a new language and new paradigms. In M. Rahnema and V. Bawtree (Eds), The Post-Development Reader. London: Zed Books, pp. 377-403.

Redclift, M. (1987) Sustainable Development: Exploring the Contradictions. London: Routledge.

Rist, G. (2019) The History of Development: From Western Origins to Global Faith, $5^{\text {th }}$ Edn. (trans. P. Camiller). London: Zed Books.

Robinson, L. (2004) Squaring the circle? Some thoughts on the idea of sustainable development. Ecological Economics, 48(4), 369-84.

Ruhanen, L., Weiler, B., Moyle, B.D. and McLennan, C.L.J. (2015) Trends and patterns in sustainable tourism research: A 25-year bibliometric analysis. Journal of Sustainable Tourism, 23(4), 517-535.

Rutherford, J. (2008) Well-being, economic growth and social recession. Middlesex University e-prints. Available at: http://eprints.mdx.ac.uk/4058/1/RutherfordWell_being....pdf (Accessed 2 January 2019).

Sachs, D., Stevenson, B. and Wolfers, J. (2010) Subjective well-being, income, economic development and growth. National Bureau of Economic Research, NBER Working Paper 16441. Available at: https://www.nber.org/papers/w16441.pdf (Accessed 10 May 2020). 
Schimmel, J. (2009) Development as happiness: The subjective perception of happiness and UNDP's analysis of poverty, wealth and development. Journal of Happiness Studies, 10(1), 93-111.

Seers, D. (1969) The meaning of development. International Development Review 11(4), 2-6.

Seers, D. (1977) The new meaning of development. International Development Review, 19(3), 2-7.

Sen, A. (1999) Development as Freedom. New York: Anchor Books.

Sharpley, R. (2000) Tourism and sustainable development: Exploring the theoretical divide. Journal of Sustainable Tourism, 8(1), 1-19.

Sharpley, R. (2015) Tourism: A vehicle for development? In R. Sharpley and D. Telfer (Eds), Tourism and Development: Concepts and Issues, $2^{\text {nd }}$ Edn. Bristol: Channel View Publications, pp. 3-30.

Sharpley, R. and Pearce, T. (2007) Tourism, marketing and sustainable development in the English national parks: The role of national park authorities. Journal of Sustainable Tourism, 15(5), 557-573.

Sidaway, J. (2007) Spaces of post-development. Progress in Human Geography, 3(3), 345361.

Skolimowski, H. (1995) In defence of sustainable development. Environmental Values 4(1), 69-70.

Smith, V.L. and Eadington, W.R. (Eds) (1992) Tourism Alternatives: Potentials and Problems in the Development of Tourism. Philadelphia: University of Pennsylvania Press

Statista (2020) Low cost carriers' worldwide market share from 2007 to 2018. Statista.

Available at: https://www.statista.com/statistics/586677/global-low-cost-carriermarket-capacity-share/ (Accessed 31 January 2020).

Stiglitz, J. (1998) Towards a new paradigm for development: Strategies, policies processes. Prebisch Lecture, UNCTAD, Geneva, 19 October. Available at: https://pdfs.semanticscholar.org/a0b9/3b3aeeb17cfce3c8c4f2bd67beb8562f195a.pdf (Accessed 10 February 2020)

Stoval, W., Higham, J. and Stephenson, J. (2019) Prepared for take-off? Anthropogenic climate change and the global challenge of twenty-first century tourism. In D. Timothy (Ed.). Handbook of Globalisation and Tourism Cheltenham: Edward Elgar, pp. 174-187. 
Tanguay, G.A., Rajaonson, J. and Therrien, M.C. (2013) Sustainable tourism indicators: Selection criteria for policy implementation and scientific recognition. Journal of Sustainable Tourism, 21(6), 862-879.

Torkington, K., Stanford, D. and Guiver, J. (2020) Discourse(s) of growth and sustainability in national tourism policies. Journal of Sustainable Tourism. DOI:

$10.1080 / 09669582.2020 .170695$

UN (n.d.) Sustainable Development Goals. United Nations. Available at: https://sustainabledevelopment.un.org/?menu=1300 (Accessed 31 January 2020).

UNDP (2010) Human Development Report 2010. The Real Wealth of Nations: Pathways to Human Development. New York: United Nations Development Programme. Available at:

http://hdr.undp.org/sites/default/files/reports/270/hdr_2010_en_complete_reprint.pdf (Accessed 12 February 2020)

UNDP (2019) Human Development Report 2019. Beyond Income, Beyond Averages, Beyond Today: Inequalities in Human Development in the $21^{\text {st }}$ Century. New York: United Nation Development Program. Available at:

http://hdr.undp.org/sites/default/files/hdr2019.pdf (Accessed 12 February 2020).

UNWTO (2004) Indicators of Sustainable Development for Tourism Destinations. Madrid:

World Tourism Organization.

UNWTO (2019) Tourism Highlights 2019 Edition. Madrid: UN World Tourism Organization.

UNWTO/UNDP (2017) Tourism and the Sustainable Development Goals - Journey to 2023.

UN World Tourism Organization / United Nation Development Programme. Available at: https://www.undp.org/content/dam/undp/library/Sustainable\%20Development/UNWT O_UNDP_Tourism\%20and\%20the\%20SDGs.pdf (Accessed 3 February 2020).

Veenhoven, R. and Vergunst, F. (2014) The Easterlin illusion: Economic growth does go with greater happiness. International Journal of Happiness and Development, 1(4), 311-343.

Ward, J., Sutton, P., Werner, A., Costanza, R., Mohr, S. and Simmons, C. (2016) Is decoupling GDP growth from environmental impact possible? PLOS One, 11(10). DOI: 10.1371/journal.pone.0164733

WCED (1987) Our Common Future. Oxford: Oxford University Press. 
Weston, R., Davies, N.J., Lumsdon, L.M., McGrath, P., Peeters, P., Eijgelaar, E. and Piket, P. (2012) The European Cycle Route Network, EuroVelo. European Parliament: Policy Department B: Structural and Cohesion Policies. Available lat: https://www.cstt.nl/userdata/documents/the\%20european\%20cycle\%20route\%20netw ork\%20eurovelo_english.pdf (Accessed 11 May 2020)

Wheeller, B. (1991) Tourism's troubled times: Responsible tourism is not the answer. Tourism Management, 12(2), 91-96.

Wilkinson, R. and Pickett, K. (2010) The Spirit Level: Why Equality is Better for Everyone. London: Penguin.

World Bank (2019) Air transport, passengers carried. World Bank Data. Available at: https://data.worldbank.org/indicator/IS.AIR.PSGR (Accessed 31 January 2020).

World Data Atlas (2018) Contribution of Travel and Tourism to Total GDP. Available at: https://knoema.com/atlas/topics/Tourism/Travel-and-Tourism-Total-Contribution-toGDP/Contribution-of-travel-and-tourism-to-GDP-percent-of-GDP (Accessed 30 December 2018).

WTO (1980) Manila Declaration on World Tourism. Madrid: World Tourism Organization.

WTTC (n.d.) Sustainable Growth. World Travel \& Tourism Council. Available at: https://wttc.org/en-gb/Initiatives/Sustainable-Growth (Accessed 11 May 2020).

Young, G. (1973) Tourism: Blessing or Blight? Harmondsworth: Penguin. 